\title{
Identification and Creation of Optimum Habitat Conditions for Livestock
}

\author{
Derek W. Bailey \\ Author is Associate Professor, Department of Animal and Range Sciences, New Mexico State University, Las Cruces, NM 88003.
}

\begin{abstract}
Optimum habitat condition is a concept typically used for wildlife rather than livestock. The definition for optimal livestock habitat will vary with management objectives. Abiotic factors, such as topography, water availability, and thermal cover, affect animal performance and uniformity of grazing. Livestock usually prefer gentle slopes and avoid traveling long horizontal and vertical distances to water. Shade and nearby water are used for thermoregulation when temperatures are high, and topographic relief and woody vegetation can be used for thermal cover during cooler temperatures. Biotic factors, such as forage quality and quantity, influence spatial grazing preferences and affect animal performance. Livestock prefer areas with higher forage quality and quantity. Uniformity of grazing may be greater in homogeneous vegetation, but animal performance may be greater in heterogeneous vegetation, especially at lower stocking rates. Livestock grazing patterns have been predicted using multiple regression and other models, but their success has typically been limited to a specific site. Managers can improve livestock habitat conditions by changing abiotic attributes of the pastures, such as developing water, building structures for thermal cover, and changing biotic attributes of the pasture through burning, fertilizing, varying stocking rates, and manipulating grazing systems. Managers can also choose animals that are more adapted to specific rangeland conditions. Practices such as strategic supplementation and herding can modify livestock behavioral patterns to use more of the available habitat. The spatial and temporal variability of rangeland requires multiple management practices to optimize use of livestock habitat.
\end{abstract}

\section{Resumen}

La condición óptima del hábitat es un concepto usado típicamente para fauna silvestre mas que para el ganado. La definición del hábitat óptimo para el ganado puede variar con los objetivos de manejo. Factores abióticos tales como topografía, disponibilidad de agua, y cobertura termal afectan el comportamiento animal y la uniformidad de apacentamiento. El ganado usualmente prefiere pendientes suaves y evita viajar grandes distancias horizontales y verticales para abrevar. La sombra y la cercanía del agua son usados para fines de termorregulación cuando las temperaturas son altas y el relieve topográfico y la vegetación leñosa pueden ser usadas para cobertura termal durante las temperaturas frías. Los factores bióticos tales como la calidad y cantidad de forraje influencian las preferencias espaciales de apacentamiento y afectan el comportamiento animal. El ganado prefiere áreas con una mayor cantidad y calidad de forraje. La uniformidad del apacentamiento puede ser mayor en una vegetación homogénea, pero el comportamiento productivo animal puede ser mayor en una vegetación heterogénea, especialmente con cargas animal baja. Los patrones de apacentamiento del ganado han sido predichos usando técnicas de regresión múltiple y otros modelos, pero su éxito has sido típicamente limitado a un sitio específico. Los manejadores pueden mejorar las condiciones de hábitat del ganado cambiando los atributos abióticos de los potreros como desarrollando aguajes, construyendo estructuras para cobertura termal y cambiando los atributos bióticos del pastizal a través de la quema, fertilización, variando la carga animal y manipulando los sistemas de apacentamiento. Los manejadores también pueden escoger animales que están más adaptados a ciertas condiciones específicas del pastizal. Practicas tales como la suplementación específica y la formación de hatos pueden modificar los patrones de comportamiento del ganado para usar más del hábitat disponible. La variabilidad espacial y temporal del pastizal requiere de múltiples prácticas de manejo para optimizar el uso del hábitat del ganado.

Key Words: distribution, grazing, foraging, behavioral mechanisms, management

\section{INTRODUCTION AND DEFINITIONS}

Habitat is the arrangement of environmental factors, such as food, cover, and water, that a given species needs to survive and reproduce in a given area (Treferthen 1964; Thomas 1979). Optimal habitat conditions for wildlife often refer to conditions

This manuscript has been assigned Journal Series No. 2003-30, Montana Agricultural Experiment Station, Montana State University, Bozeman.

Correspondence: Dr Derek W. Bailey, Dept of Animal and Range Sciences, New Mexico State University, Las Cruces, NM 88003. Email: dwbailey@nmsu.edu

Manuscript received 23 March 2003; manuscript accepted 1 June 2004. that will support the highest densities of a species. For example, habitat suitability index models are used to evaluate the quality of an area for supporting a specific species (US Fish and Wildlife Service 1976), and population densities are often used to verify the models (Allen et al. 1984). Optimal conditions for foraging have been widely evaluated using optimal foraging theory (Stephens and Krebs 1986). Optimal foraging locations using this theory are usually defined as those that maximize the average energy intake rate.

For livestock, the optimal habitat and foraging locations using these definitions would be feedlots. Animal densities and energy intake rates are purposely kept high to maximize 
weight gain and ensure that inputs including management and labor are used efficiently. For livestock grazing rangeland, definitions of optimal habitat conditions must consider management goals and objectives. May et al. (2002) found that economic optimal stocking rates were lower if leases were longer or if the lease was made on a per head basis with no constraints. Leases with short-term planning horizons (e.g. 1 year) or based on a per acre basis resulted in higher optimal stocking rates. For maximum individual animal performance, optimal stocking rates are much lower than maximum live weight gain per hectare (Hart et al. 1988). Other resource concerns, such as fisheries and wildlife habitat and the sustainability of grazing, could also be an important aspect of the definition of optimum habitat conditions for livestock, especially on public lands.

For this discussion, optimal habitat conditions refer to situations and management that should result in favorable animal performance without adversely affecting the sustainability of grazing or other rangeland resource concerns. Conditions that would maximize profitability of the livestock enterprise without concerns to other resources might differ from those discussed here. A major assumption of this paper is that uniformity of livestock use is a critical component of sustainable grazing management (Vallentine 2001). Concentration of livestock grazing use within a pasture can result in adverse impacts to vegetation productivity, water quality, wildlife habitat, and other natural resource concerns (Fuls 1992a, 1992b). Many of the concerns regarding livestock grazing on rangelands are the result of uneven livestock distribution rather than inappropriate stocking rates. Animal distribution is a fundamental component of any discussion of habitat. The extent that animals avoid or prefer certain portions of a pasture or landscape help determine the area's role as habitat. In addition, the economic sustainability of livestock grazing must be considered if it is to remain viable. Thus, effects of certain habitat characteristics and management practices on livestock performance and the economic costs and benefit of implementing various management practices are mentioned. The overall objectives of this discussion are to describe how 1) habitat factors can affect uniformity of livestock grazing and livestock performance, 2) management can modify habitat factors that limit uniformity of grazing and animal performance, and 3) management can be used to manipulate livestock behavior so that animals graze more uniformly and are more adapted to their environment.

\section{CHARACTERISTICS OF LIVESTOCK HABITAT}

Habitat consists of abiotic and biotic factors. Abiotic factors include the availability of water and shelter and affect the effort required to find food (e.g. topography), while biotic factors relate primarily to the quantity and quality of food (Senft et al. 1987; Bailey et al. 1996). This is also useful because abiotic factors exhibit fewer seasonal trends than biotic factors. Topography and shelter often remain constant throughout the year. Some water sources are perennial, while others are ephemeral and may dry up during droughts. On the other hand, biotic factors change seasonally and annually.

\section{Abiotic Factors}

Water. Water is the most critical component of livestock habitat. Sufficient water must be available for the number and type of animals given the current and expected climatic conditions. Ambient temperature, activity, and lactation status can all affect water requirements (National Research Council 1996). Availability of water can limit the season of use of pastures in arid regions. For example, water from snowmelt may provide sufficient water for spring grazing, while in the summer there may be inadequate water after ephemeral water sources dry out. The presence of snow during the fall and winter may reduce the amount of water livestock must drink. For example, Bailey et al. (2000) found that a cow tracked by a global positioning satellite (GPS) collar did not visit any water sources for 6 consecutive days in January when snow was available. The greater water requirement of lactating cows and the behavioral requirements of caring for a calf can limit use of rugged terrain. Nonlactating cows in Montana traveled farther vertically from water and in some cases used steeper slopes than lactating cows (Bailey et al. 2001b). A study in Oregon found that cows whose calves have been weaned graze farther from riparian areas than cows nursing calves (T. DelCurto et al., unpublished data).

Horizontal distance to water has been recognized as an important factor in livestock grazing distribution for over 55 years. Valentine (1947) found that forage utilization on gentle terrain in New Mexico was 50\% at distances of $0-0.8 \mathrm{~km}, 30 \%$ at $1.6 \mathrm{~km}$, and only $12 \%$ at $3.2 \mathrm{~km}$. Holechek (1988) recommended reducing the grazing capacity of rangeland that is $1.6-3.2 \mathrm{~km}$ from water by $50 \%$ and considering areas further than $3.2 \mathrm{~km}$ from water as unusable. In rough topography, the relationships between grazing use and distance to water may differ from those observed in gentle terrain. Gillen et al. (1984) found that cattle preferred areas within $200 \mathrm{~m}$ of water and avoided areas greater than $600 \mathrm{~m}$ from water in mountainous terrain of northeastern Oregon. In another study conducted in the Blue Mountains of Oregon, cattle avoided areas further than $2 \mathrm{~km}$ from water (Roath and Krueger 1982), but vertical distance appeared to be more important than horizontal distance to water. Cows did not graze at elevations that were $80 \mathrm{~m}$ above water.

Slope. Slope is another important abiotic factor affecting grazing distribution in rough terrain. Gillen et al. (1984) reported that cattle avoid slopes in excess of $20 \%$. Holechek (1988) recommends reducing estimated grazing capacities by $30 \%$ for areas with slopes between $11 \%$ and $30 \%$ and reducing capacity by $60 \%$ for areas with slopes between $31 \%$ and $60 \%$. Holechek (1988) also recommends considering areas with slopes over $60 \%$ as unusable, but no reduction in grazing capacity is recommended for gentle slopes $(0 \%-10 \%)$. In Utah, slope was an important indicator of forage utilization on mountain rangeland, but interactions with other components of terrain made the relationships complex (Cook 1966). No single measure of slope adequately predicted use of rough topography. Grazing use decreased if nearby slopes were steep or if slopes were steep on the way to the site or to the nearest water. On gentler slopes, distance to water became more important. Muggler (1965), in a southwestern Montana study, combined slope and distance 

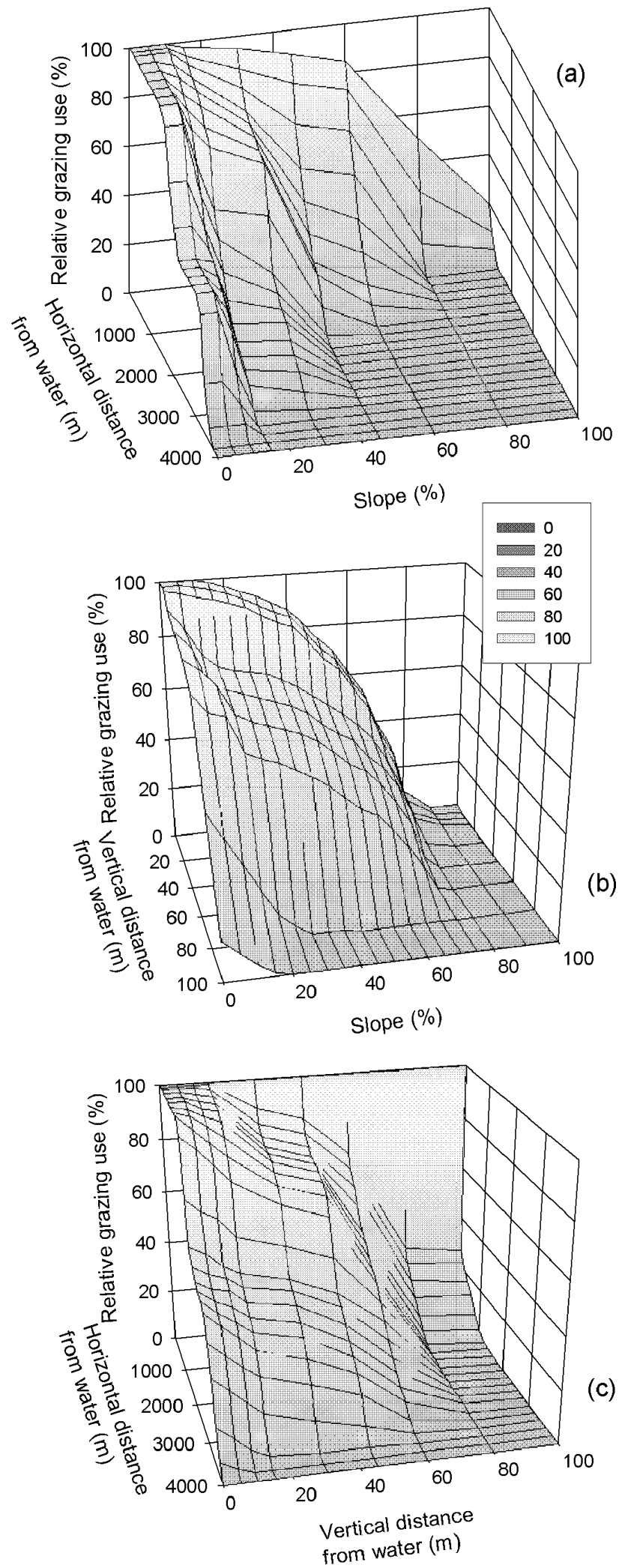

Figure 1. Integration of effects of slope, horizontal distance to water, and vertical distance to water on grazing use. Relationships between hypothetical grazing use and terrain attributes are adapted from Holechek (1988), Holechek et al. (2001), Muggler (1965), and Roath and Krueger (1982). Hypothetical grazing use varies from 0\% (abiotic factors prevent livestock from grazing the area) to $100 \%$ (no restriction from abiotic factors, e.g. level terrain near water). Relationships are upslope to predict cattle distribution. Distance upslope was closely related to distance to water in this study because water was located near slope bottoms. Cattle use was less on steeper slopes and at further distances upslope. For example, $75 \%$ of cumulative cattle use was within $800 \mathrm{~m}$ of the bottom of gentle slopes (10\% slope). On steeper gradients (30\% slope), $75 \%$ of the use was within $400 \mathrm{~m}$ of the slope bottom.

Integration of Terrain Attributes. To adequately address the effects of terrain and distance to water on livestock use, we must combine the effects of slope, horizontal distance to water, and vertical distance to water and develop an integrated indicator of terrain use. Figure 1 gives hypothetical relationships between slope and horizontal distance to water, between slope and vertical distance to water, and between horizontal and vertical distance to water. For gentler topography or more arid areas where water availability is limited, the relationship between slope and horizontal distance to water (Fig. 1a) may be more useful for identifying potential differences in grazing use within pastures than slope and vertical distance to water. In many mountain pastures, horizontal distance to water is not an issue, and the relationship between slope and vertical distance to water (Fig. 1b) may be more accurate for identifying potential differences in grazing use than the relationship identified in Figure 1a. It is important to note that these relationships are useful for identifying only relative differences in expected grazing use. As discussed later, management practices can improve uniformity of grazing and help overcome differences in grazing use that result from rough terrain or limited water sources.

Considerations for Thermoregulation. Livestock must expend additional energy to maintain body temperature when temperatures are above or below the zone of thermoneutrality (National Research Council 1996) and seek out shelter to avoid extremes of heat and cold. In California, cows spent about 8 hours per day under shade trees during sunny summer days (Harris et al. 2002). During the winter, these cows avoided shade trees and grazed warmer southern exposures. In Colorado shortgrass rangeland, cattle rested in sandy sites during the summer (Senft et al. 1985b). Sandy soils should dissipate heat more rapidly than fine-textured soils. During the winter, cattle preferred to rest in protected sinkholes during windy weather and in sites with thick mats of buffalo grass (Buchloe dactyloides [Nutt.] Engelm) that may have provided some insulation against cold soil. In Montana, cattle sought out protected microsites within a pasture to avoid high wind speeds combined with low temperatures (Houseal and Olson 1995). Rangeland with trees, shrubs, and variable terrain provide livestock opportunities to seek out sites with more favorable climatic conditions so that body temperature can be maintained.

presented as slope and horizontal distance to water (a), slope and vertical distance to water (b), and horizontal distance to water and vertical distance to water (c). The effects of all terrain attributes (slope and horizontal and vertical distance to water) on hypothetical grazing use could be combined using approaches such as multiple regression. 


\section{Biotic Factors}

Forage Quantity and Quality. Forage quantity and quality are important biotic factors that influence where livestock graze. Livestock are attracted to patches and plant communities with greater levels of forage quality and quantity (Bailey et al. 1996). In north-central Wyoming, Smith et al. (1992) found that cattle only spent about $20 \%$ of their time in a plant community with a standing crop of $150 \mathrm{~kg} \cdot \mathrm{ha}^{-1}$ that encompassed $82 \%$ of the total pasture area and spent about $80 \%$ percent of their time in 2 plant communities with standing crops of 382 and 730 $\mathrm{kg} \cdot \mathrm{ha}^{-1}$ that made up only $18 \%$ of the pasture. In Colorado shortgrass rangeland, Senft et al. (1985a) found that yearling heifers' preference for plant communities was most closely correlated to standing nitrogen $\left(\mathrm{kg} \mathrm{N} \cdot \mathrm{ha}^{-1}\right.$, a variable that combines standing crop and nutrient concentration). In Wyoming foothill rangeland (Pinchak et al. 1991), cattle also preferred plant communities with greater levels of standing nitrogen (5.0$16.5 \mathrm{~kg} \mathrm{~N} \cdot \mathrm{ha}^{-1}$ ) and avoided plant communities with lower levels $\left(2.9-4.8 \mathrm{~kg} \mathrm{~N} \cdot \mathrm{ha}^{-1}\right)$. Riparian areas and meadows often provide 1.5-6 times greater quantities of forage with similar or sometimes slightly greater crude protein concentrations than found in uplands, which may help explain why cattle spend a disproportionate amount of time in riparian areas (Roath and Krueger 1982; Gillen et al. 1984; Smith et al. 1992; Parsons et al. 2003).

Heterogeneity of Forage. Heterogeneity of forage can affect uniformity of grazing. Early in the growing season when forage quality is high, pastures (often monocultures) with uniform vegetation will provide ample high-quality forage for acceptable live-weight gains. As the forages mature and forage quality begins to decline, heterogeneous vegetation may allow livestock to maintain greater levels of performance (Rittenhouse and Bailey 1996). A variety of forage species at various phenological stages (e.g. cool- and warm-season grasses) and corresponding differences in forage quality would allow livestock to select a higher-quality diet. Heterogeneity of forage does not mean only differences in species composition. Cattle use of grazed and ungrazed patches were observed in a relatively uniform stand of Lehman lovegrass (Eragrostis lehmanniana Nees) near Tucson, Arizona (Ruyle and Rice 1996). Presence of heavily grazed patches and wolf plants were maintained from one year to the next. Overall, cattle spent about $80 \%$ of their grazing time in previously grazed patches. Lower relative stocking rates would allow individual animals to be more selective and benefit more from heterogeneous vegetation. For example, Hart et al. (1991) found that cattle grazed the most-preferred sites at the exclusion of other sites when stocking rate was dropped from moderate levels to light to very light levels in Wyoming foothill rangeland. Ruyle and Rice (1996) found that grazing use of the previously grazed and preferred patches of Lehman lovegrass was greater at moderate stocking rates $(89 \%)$ than at heavy stocking rates $(68 \%)$. Cows were apparently forced to use lovegrass that was not previously grazed in pastures with the heavy stocking rate.

Although the presence of variability in forage and grazing sites may ensure that animals can be selective, forage and topographic heterogeneity often reduces the uniformity of grazing. Steers alternated among feeding sites in a homogeneous area, but in a heterogeneous area steers avoided a site with a higher standing crop and lower forage quality for 21 consecutive days after their first visit (Bailey 1995).

\section{Modeling Livestock Grazing Distribution}

Existing Models. A great deal of effort has been spent attempting to predict livestock grazing patterns and develop management practices to increase uniformity of grazing in heterogeneous areas. Attempts to model livestock grazing distribution have had variable success. Cook (1966) and Gillen et al. (1984) concluded that grazing distribution could not be predicted on mountain rangeland with reasonable precision using multiple regression models. Ad hoc regression models are site specific and often limited in predictive ability for different areas (Senft et al. 1985a). Use of relative indices of spatial preference and forage attributes was suggested as an alternative to regression models (Senft 1989). Coughenour (1991) suggested that models should integrate plant growth and ungulate movement and foraging patterns. This author also recommended that models be spatially explicit and that abiotic constraints, such as topographical features, be integrated with animal responses to forage (biotic) attributes. Brock and Owensby (2000) developed a spatially explicit model for predicting livestock grazing patterns using geographical information systems software. The model included range site, topographic, and other physical features. The authors concluded that their model's lack of predictive ability was due to its lack of forage quantity and quality characteristics. Bailey et al. (1996) described a conceptual model that incorporated the abiotic constraints of topography with relative forage quality and quantity characteristics using cognitive behavioral processes, such as spatial memory. One important factor that this model did not address was the effect of thermal regulation on livestock grazing patterns. Recent research (e.g. Harris et al. 2002) has demonstrated the importance of spatial variation in climatic conditions within pastures in California foothill rangeland. During the summer, cattle avoided southern exposures and other areas in the pastures where temperatures were relatively higher and sought out shade during midday. In winter, cows often grazed on ridges and other areas of higher elevation where temperatures were warmer than valleys and lower elevations. Differences in temperature that occur within pastures with variable topography may constrain where livestock graze. Until recently, mechanistic models, such as that suggested by Bailey et al. (1996), required collection of animal tracking data for model verification. Until the development of GPS collars (Moen et al. 1997), such tracking was not practical. Development of spatially explicit models that incorporate recent research on grazing distribution with previously established relationships with abiotic and biotic factors is needed.

Proposed Model. The following simplified conceptual model is an update of the mechanistic model presented by Bailey et al. (1996). The purpose for including the model is to show how management can affect behavioral mechanisms and how management can overcome livestock grazing distribution problems that may arise in various habitats.

This individual animal-based model assumes that livestock retain information regarding feeding sites based on previous 
experience (Fig. 2). The stored information for each feeding site is summarized to a relative rating that can be used to determine which feeding sites will be grazed next. The relative rating is based on an integration of abiotic and biotic factors. Abiotic factors include slope, distance to water (horizontal and vertical), and barriers (Fig. 1). Biotic factors include forage quality, forage quantity, and secondary compounds. With the exception of weather, abiotic factors usually remain somewhat constant, while biotic factors may change because of forage growth, senescence, and grazing (feedback from feeding site selection). Animals select a feeding site in which to graze based on the ratings. This selection process is based on hypothetical foraging goals (Senft et al. 1987), such as a reducing travel effort, increasing nutrient capture rate, maintaining body temperature, and continuing the interaction of satiety and variety (Provenza et al. 2003). Once an animal selects a feeding site, the decision can be modified by weather conditions, social interactions, and herding (Fig. 2).

\section{DEVELOPMENT OF MORE FAVORABLE LIVESTOCK HABITAT}

Managers can change aspects of rangeland pastures to make habitat conditions more favorable for livestock. The goals of these modifications may be to improve uniformity of grazing, livestock gain, or reproductive performance. Rather than changing abiotic and biotic characteristics of the livestock habitat, managers can also manipulate the behavior of the animals so that grazing can meet management objectives (Fig. 1; Table 1). Although management practices that improve livestock habitat conditions and animal behavior have been recommended for over 45 years to improve uniformity of grazing (Williams 1954), recent research has provided us with new insights and applications of these management practices.

\section{Modification of Abiotic Factors}

Water Developments. Development of new sources of water will improve habitat conditions of most rangeland pastures because water is the most critical nutrient requirement of livestock. Development of additional water has been the most common recommendation for improving livestock grazing distribution for several decades (Williams 1954). Water developments reduce the distance that animals must travel to water for some feeding sites (Table 1), which should make these sites more attractive (or less aversive) to livestock. In eastern Oregon, cows dramatically changed their grazing patterns when the only available water source was moved within the pasture (Ganskopp 2001). Cattle also changed their grazing use of riparian areas of when water was pumped to a tank away from the stream in northeastern Oregon (Porath et al. 2002). Cows and calves in this study that had access to an off-site water source and supplemental salt gained 0.27 and $0.14 \mathrm{~kg} \cdot \mathrm{d}^{-1}$ more, respectively, than cattle without off-stream water and salt. During the winter, providing off-site water reduced grazing use of riparian areas in another Oregon study (Miner et al. 1992). Water developments require a substantial capital investment. Producers and land managers should carefully consider the costeffectiveness of water developments (Williams and Lacy 1995).

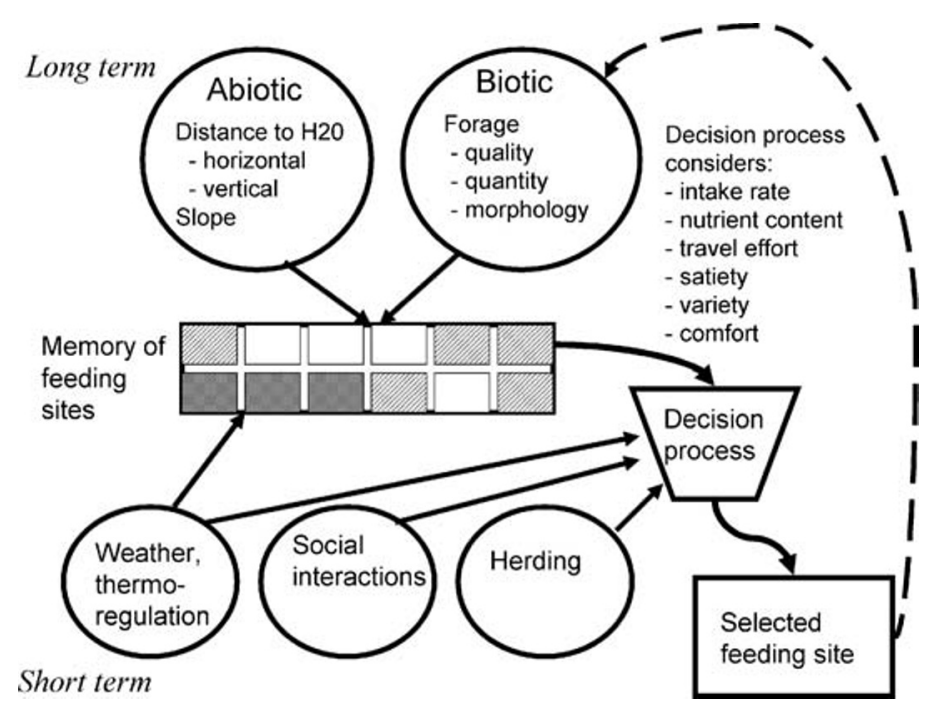

Figure 2. Conceptual model of feeding site selection. This model is an update of the model presented by Bailey et al. (1996) and indicates how management may affect feeding site selection. Animals rate individual feeding sites based on abiotic and biotic factors. Animals select among feeding sites using these relative ratings in an effort to maximize nutrient capture rate, minimize travel effort, and maintain thermoneutrality. The interaction between the desire to maintain satiety and seek out variety (Provenza et al. 2003) is also important. The individual's selection of a feeding site can then be modified by weather conditions, social interactions, and herding. Grazing of selected sites affect (a feedback loop) the site's biotic characteristics (forage quantity and quality). For the memory of feeding sites, white boxes represent good ratings (e.g. riparian areas in the summer), boxes with slashes represent intermediate ratings (moderate-sloped uplands in the summer), and solid gray boxes represent poor ratings (high and steep uplands in the summer).

In analyses conducted 35 years ago, Workman and Hooper (1968) found that the economic returns for some types of water developments, such as guzzlers, did not justify the investment based on additional livestock carrying capacity, while spring developments and pond construction were usually cost effective. Recent analyses conducted by Stillings et al. (2003) showed that off-spring water developments and salt placement could potentially increase expected annual net returns by $\$ 4500-\$ 11000$ for a 300-head cow-calf operation using public lands with typical riparian area management considerations.

Trail Construction. Cattle establish least-effort routes between distant points in rugged terrain (Ganskopp et al. 2000). Livestock may not be able to develop trails if the terrain is extremely rocky and rugged or if barriers, such as thick timber, are present. In canyon areas of New Mexico, development of trails greatly improved uniformity of grazing (R. Hartley, personal communication). Trails allowed cows to easily travel to areas far from water before grazing steep and rocky slopes. Logging roads in mountainous Oregon rangeland increased grazing use of nearby areas in steep and rugged terrain (Roath and Krueger 1982). In areas with more gentle terrain, roads did not appear to be an important factor in distribution.

Shelter. Although we cannot change the topographic relief of livestock habitat, managers can build structures and plant 
Table 1. Effects of grazing distribution practices on behavioral mechanisms affecting the selection of feeding sites by livestock.

\begin{tabular}{|c|c|c|c|c|}
\hline \multirow[b]{2}{*}{ Management Practice } & & $\begin{array}{l}\text { Habitat Factor that is } \\
\text { Affected by Management }\end{array}$ & \multirow{2}{*}{$\begin{array}{l}\text { Behavioral Mechanism Affected } \\
\text { by Management or Consequence } \\
\text { to Animal from Management }\end{array}$} & \multirow[b]{2}{*}{$\begin{array}{l}\text { Expected Change in Grazing } \\
\text { Distribution by Management }\end{array}$} \\
\hline & Type & $\begin{array}{c}\text { Management Effect on } \\
\text { Habitat Factor }\end{array}$ & & \\
\hline Water Development & Abiotic & $\begin{array}{l}\text { Horizontal and vertical distance to } \\
\text { water will be reduced in some } \\
\text { areas of the pasture }\end{array}$ & $\begin{array}{l}\text { Reduced effort to travel to foraging } \\
\text { sites near water development }\end{array}$ & $\begin{array}{l}\text { Increased grazing use near water } \\
\text { development }\end{array}$ \\
\hline Trail Development & Abiotic & $\begin{array}{l}\text { Paths are developed in the pasture, } \\
\text { typically in rough terrain }\end{array}$ & $\begin{array}{l}\text { Reduced travel effort to foraging } \\
\text { sites near developed trail }\end{array}$ & $\begin{array}{l}\text { Increased use of areas near } \\
\text { developed trail }\end{array}$ \\
\hline Fencing & Abiotic & $\begin{array}{l}\text { Terrain and plant communities } \\
\text { enclosed }\end{array}$ & Available choices of feeding sites & $\begin{array}{l}\text { Livestock can be restricted to } \\
\text { certain sites and excluded from } \\
\text { others; opportunity to increase } \\
\text { homogeneity of enclosed } \\
\text { vegetation }\end{array}$ \\
\hline Burning or Fertilization & Biotic & $\begin{array}{l}\text { Forage quality and quantity may } \\
\text { increase in treated sites }\end{array}$ & $\begin{array}{l}\text { Nutrient capture rate may increase } \\
\text { in treated sites }\end{array}$ & $\begin{array}{l}\text { Livestock will prefer treated sites } \\
\text { over untreated sites }\end{array}$ \\
\hline $\begin{array}{c}\text { Strategic Supplement Placement } \\
\text { (Including Salt and Minerals) }\end{array}$ & None & None & $\begin{array}{l}\text { Palatable feed available at certain and } \\
\text { sometime distant feeding locations; } \\
\text { after travel to supplement, travel } \\
\text { effort to nearby feeding sites } \\
\text { is minimal }\end{array}$ & $\begin{array}{l}\text { Animals are lured to areas near } \\
\text { supplement placement }\end{array}$ \\
\hline $\begin{array}{l}\text { Selection of More Adapted } \\
\text { Breeds or Individual } \\
\text { Animals }\end{array}$ & None & None & $\begin{array}{l}\text { Perceived travel effort for adapted } \\
\text { animals is less than for } \\
\text { unadapted animals }\end{array}$ & $\begin{array}{l}\text { Selected animals will travel further } \\
\text { and use rougher terrain than } \\
\text { culled animals }\end{array}$ \\
\hline Herding & None & None & $\begin{array}{l}\text { Animals are not allowed to travel } \\
\text { directly to the feeding site they } \\
\text { selected and are herded to } \\
\text { another location }\end{array}$ & $\begin{array}{l}\text { Feeding site for the herd is } \\
\text { selected by management }\end{array}$ \\
\hline
\end{tabular}

trees and shrubs to provide shade and windbreaks. Providing shade structures increased live-weight gains of steers during the summer in Oklahoma (McIlvain and Shoop 1971). The shade structures appeared to be an attractant, and the authors suggested using shade structures as a method for manipulating grazing distribution. In northeastern Nevada, Davison and Neufeld (1999) built structures to provide shade for cattle with the goal of reducing the time cattle spent in riparian areas. Cattle used the shade structures, but their presence did not significantly reduce cattle use of riparian areas. The effectiveness of man-made windbreaks during the winter was evaluated in Montana (Olson et al. 2000; Olson and Wallander 2002). Cattle used the structures during windy weather, especially when temperatures were low. The presence of windbreaks had minimal effect on animal performance. The authors concluded that cattle in adequate body condition were physiologically and behaviorally adapted for the climatic conditions incurred during Montana winters. Results from this study may have differed if the study animals had originated and recently moved from an area with mild winter weather conditions. The value of shelter construction for increasing uniformity of grazing and improving animal performance appears limited, but further research is needed to determine if man-made structures may be helpful for animals that are moved to environments that differ greatly from those they were adjusted to.

\section{Modification of Biotic Factors}

Improving Forage Quantity and Quality. Burning and fertilization can improve forage quality and be used to manipulate grazing distribution. Livestock are attracted to areas that have been recently burned or fertilized. Strategic fertilization was used to create firebreaks in native bluegrass range (Williams 1954). Studies in the tallgrass prairie found that bison prefer to graze in areas that were recently burned (Coppedge and Shaw 1998; Biondini et al. 1999). Hooper et al. (1969) suggested that cattle use of fertilized and nearby unfertilized areas might make this management practice more feasible. Ball et al. (2000) found that moose preferred to graze sites in a boreal forest that were fertilized over sites that were not fertilized, and the authors suggested that fertilization might be a tool for modifying where moose and other herbivores graze. Further evaluations of the economic feasibility of burning and fertilization as tools to increase uniformity of grazing and animal performance are needed, especially considering the increasing cost of fertilizer and potential risks associated with prescribed burning.

Changing Heterogeneity of Vegetation. Heterogeneity of vegetation within a pasture can be changed through fencing. If pastures are fenced so that the vegetation is more homogeneous, it is likely that grazing will be more uniform (Bailey and 
Rittenhouse 1989; Bailey 1995). For example, moderate-size crested wheatgrass (Agropyron cristatum [L.] Gaertn.) pastures are used more uniformly if they are a monoculture than if the crested wheatgrass seedings are interspersed with native range. The concept of "riparian pastures" is another example of changing the heterogeneity of available vegetation through fencing (Fig. 3). Riparian grazing is more easily managed when upland areas are not enclosed with streamside vegetation. The choices among foraging sites are more similar, and grazing is more likely to be uniform. Anecdotal observations of this concept are available, but scientific research on this proposed practice appears warranted.

Changing the season of grazing is another approach for reducing the heterogeneity of vegetation and increasing uniformity of grazing. Parsons et al. (2003) have shown that cattle spend more time grazing uplands and do not concentrate on riparian zones if grazing occurs earlier in the season. Forage quality is greater earlier in the year, and the relative difference between upland and riparian forage is smaller earlier in the summer as opposed to later in the season when upland forage begins to mature. Similarly, fall grazing of rugged mountain pastures is more uniform because differences in forage quality are less when forage throughout the pasture is mature (DelCurto et al. 1999).

Grazing systems (such as rest-rotation and rotationally deferred grazing systems) are designed to overcome selective grazing in heterogeneous vegetation (Holechek et al. 2001). By changing the timing, duration, and frequency of grazing, preferred plants and preferred feeding sites can be given sufficient rest to maintain their health and vigor.

\section{Modification of Behavior}

Use of More Adapted Animals. Ruminant livestock vary in their ability to use extensive rangeland pasture with significant vertical relief. Cattle breeds that were developed in more mountainous terrain use rough topography more uniformly than cattle breeds developed in more gentle terrain (Bailey et al. 2001a, 2001b). Recent research from Montana (D. W. Bailey, unpublished data) shows that individual cattle that previously used rougher terrain (hill climbers) continued to have more uniform grazing patterns when separated from cattle that previously used gentler terrain near water (bottom dwellers). Hill climbers spent more time at elevations at least $80 \mathrm{~m}$ above water than bottom dwellers. Hill climbers in 1 pasture spent about $20 \%$ of their active time (primarily grazing) at elevations $80 \mathrm{~m}$ above water, an area that made up $33 \%$ of the pasture. Bottom dwellers spent $12 \%$ of their time in this area. It is interesting to note that Roath and Krueger (1982) found that forage was virtually unused by cattle $(<1 \%$ utilization) in the Blue Mountains of Oregon if it was greater than $80 \mathrm{~m}$ above water. Areas that were 75 and $50 \mathrm{~m}$ above water had average forage utilization levels of $15 \%$ and $50 \%$, respectively. The recent Montana study demonstrates the potential to select individual animals that are more adapted to rugged rangeland and graze such pastures in a more sustainable manner. Howery et al. (1996) also showed that some cows preferred upland areas, while others concentrated in riparian areas. Further work by these researchers (Howery et al. 1998) showed that cows' preferences for various portions of the landscape were, at least
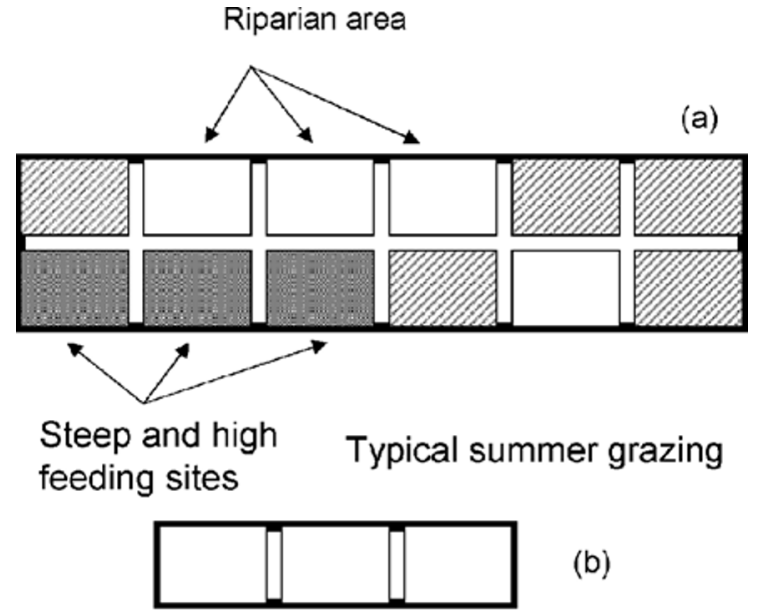

(b)

\section{Riparian area of pasture above after it was fenced separately.}

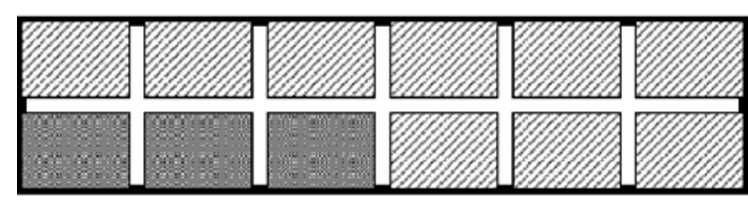

(c)

$$
\begin{aligned}
& \text { Fall grazing with no } \\
& \text { riparian pasture }
\end{aligned}
$$

Figure 3. Example of how fencing or changing the season of use can increase the homogeneity of vegetation and increase uniformity of grazing use. a, A mountain pasture in the summer with a riparian area. Riparian areas are preferentially selected over uplands because of the greater forage quality in these feeding sites and the minimal distance to water. An uneven grazing distribution pattern would be expected. b, How the feeding sites within a riparian area would be selected uniformly because there are few differences among sites. c, How the pasture shown in a might appear during autumn after all forage had matured. Differences among feeding sites are much less pronounced in autumn because the forage has matured. White boxes represent memories of feeding sites with good ratings (e.g. riparian areas in the summer). Boxes with slashes represent memories of feeding sites with intermediate ratings (moderate-sloped uplands in the summer), and the solid gray boxes represent feeding sites with poor ratings (high and steep uplands in the summer).

partially, a result of experiences learned from their dam (early learning). Animals that are more adapted to rough topography can be identified and developed through selection and training (e.g. early learning). Selection and development of these traits should not adversely affect animal performance. Bailey et al. (2001b) found that cow weight and body condition score, cow pregnancy status, and calf weaning weight were sometimes favorably related or not related to slope use and distance traveled to water (horizontal and vertical). Consequently, uniformity and sustainability of grazing could be enhanced without adverse impacts to animal performance if managers selected and developed adapted livestock when they use mountainous and extensive terrain.

Training and Experience. Older, more experienced animals may use extensive and mountainous rangeland more uniformly 
than younger animals. Mature cows grazed farther from streams than first-calf heifers in northeastern Oregon (J.A. Morrison et al., unpublished data). The older cows also appeared to have greater forage intakes as a proportion of body weight. Results from northern Montana also show that older cows use rugged terrain more uniformly than younger cows (D. W. Bailey, unpublished data). Cows that were 5 or greater years of age used steeper slopes and higher elevations than 3- and 4-year-old cows.

Older and more experienced animals often use other aspects of their habitat more efficiently. Beaver and Olson (1997) found that 7- and 8-year-old cows used protected terrain more frequently than 3-year-old cows during Montana winter conditions. Experienced animals often select higher-quality diets and avoid poisonous plants to a greater degree than naive animals (Provenza et al. 1992).

Livestock that are more adapted or more experienced with rough topography may not perceive the effort to travel farther to water, to climb higher, or to graze steeper slopes as adverse as less adapted or experienced animals. Thus, the abiotic terrain factors that contribute to animals avoiding rugged terrain will have less of an effect on adapted and more experienced individuals (Table 1).

Luring Animals to Underused Sites. Strategic placement of salt has been recommended for improving uniformity of grazing for decades (Williams 1954). Animals may travel to areas far from water to consume salt. However, salt is not as persuasive as other attractants, such as water and low-moisture molasses blocks, for luring cattle to graze underused areas (Bailey and Welling 1999; Ganskopp 2001). Strategic placement of supplement appears to be an effective tool for manipulating grazing patterns of cattle when the forage is dormant (McDougald et al. 1989; Bailey and Welling 1999). When livestock travel to distant or rugged sites to consume supplements (e.g. salt or low-moisture molasses blocks), the travel effort to reach nearby foraging sites is reduced (Table 1). Animals have already expended the effort to travel to the supplement, so the abiotic factors that would typically (without strategic supplement placement) prevent animals from grazing nearby feeding sites are minimized. Low-moisture molasses blocks appeared to affect cattle grazing patterns for distances up to $600 \mathrm{~m}$ from the site of placement (Bailey et al. 2001c). Strategic supplement placement allows managers to provide additional nutrients to their livestock during periods when forage is dormant and quality is low while at the same time allowing them to improve grazing distribution.

Herding. Although herding has been used to manipulate grazing distribution for years (Williams 1954; Skovlin 1957), its use on rangeland cattle operations has been limited. Herding requires additional labor, and its effectiveness has been questioned (Rhodes and Marlow 1997). Some producers believe that when cattle are herded away from riparian areas, "the cows beat them back to the creek." Other anecdotal observations suggest that regular herding is a very effective practice to protect riparian areas (Butler 2000). An ongoing research project in central Montana (D. W. Bailey, unpublished data) is evaluating herding and the integration of herding and strategic supplementation. Preliminary results from year 1 of this 3-year study suggest that herding and the combination of herding and strategic supplementation can help prevent excessive cattle grazing along streams. Forage stubble heights on stream banks and in riparian areas in pastures where cow-calf pairs were herded were nearly 2 times higher than in the control area with no herding.

Herding does not directly change abiotic or biotic characteristics of the habitat. Instead, herding directly changes the animal's selection of feeding sites. Livestock are prevented from choosing the feeding sites they would have selected on their own and are herded to sites selected by management (Table 1 ).

Low-stress livestock handling is gaining more popularity, and it may be very useful for herding and drifting livestock. Not only can riparian areas be protected through herding, but also animals could be moved to areas where more grazing would be beneficial (e.g. development of firebreaks or control of undesirable plant species). Herding should also be useful for increasing the use of areas, such as steep slopes and areas far from water, that typically receive little use, but quantitative evaluations should be completed to determine its effectiveness.

Integration of Management Practices. The recent work in Montana with herding and strategic supplementation suggests that an integration of management may be more persuasive than a single practice alone. Many practices may have synergistic effects. It is important to consider how various management practices and combinations of practices will change habitat condition for the livestock (Table 1). It is also important to consider practices affecting the behavioral mechanisms that result in grazing distribution patterns (Bailey et al. 1996, Fig. 2). Additional research studies and demonstration projects will help us understand and predict how producers can combine management practices to create more favorable conditions for livestock and to meet land use objectives.

\section{SUMMARY AND CONCLUSIONS}

The term "optimal habitat conditions" is often used in wildlife management, but the definition of this term should usually be changed for it to be applicable for management of grazing livestock. Areas with high animal density or areas where animals can maximize energy intake are usually considered optimal for wildlife management. Uniformity and sustainability of grazing are usually not a constraint for determining optimal habitat conditions for wildlife, but they are important components of livestock management on rangelands. At appropriate stocking rates and with proper management, livestock can graze on a sustainable basis with acceptable levels of performance on an extremely diverse set of rangeland habitats. Thus, identifying or creating optimal habitat based on animal density or maximum energy intake rate is not sufficient for grazing livestck management.

Livestock use of extensive and rugged rangeland is affected by abiotic and biotic habitat features. Topographic features and availability of water affect the effort livestock must spend in traveling to a feeding site. Animals generally avoid areas far from water, steep slopes, and higher elevations because of the additional effort required for the daily travel to and from water. Thermal regulation is an important factor in animals' behavioral repertoire. Livestock seek out shade and cooler areas during hot 
weather. In cold and windy weather, animals seek warmer sites and areas protected from the wind. Biotic factors also affect grazing distribution. Livestock prefer areas with greater levels of forage quality and quantity. Pastures with abundant water, variable but not extremely rugged terrain, and a wide variety of abundant and high-quality forage would provide the most optimal habitat for grazing livestock based on definitions used in wildlife management. However, such conditions are not typical of rangelands. Managers can change the abiotic characteristics of their pastures by developing additional water sources, developing trails, and providing shade and windbreaks. The biotic characteristics of pastures can also be changed through fertilization, burning, fencing, and changing the season of grazing. Most of these management practices, with the notable exception of changing the season of grazing, require substantial capital investments. Careful consideration of the cost-effectiveness of expensive practices is recommended. Management practices that attempt to modify grazing patterns through manipulations often require less capital expenditures. However, behavior-based management practices may involve substantial variable costs, such as labor for herding or supplement purchases. Development of simulation models that can predict the effectiveness of various management practices on a site-specific basis would be very beneficial. Simulation and other predictive models should consider the complex interactions of topography, water availability, forage quality, and forage quantity with the wide array of potential behavioral responses of livestock with and without the influence of management.

Livestock behavior is very malleable, and grazing patterns can be changed substantially through management. Ongoing research suggests that grazing patterns of livestock can be manipulated sufficiently to resolve most, if not all, resource concerns with grazing. Managers have the potential to manipulate abiotic and biotic characteristics of their pastures and/or change the animals and their behavior so that habitat conditions are favorable for the livestock and so that land use objectives can be met at the same time.

Optimal livestock habitat conditions on rangelands are those areas where uniformity and sustainability of livestock grazing are maintained and where animal performance and economic sustainability are sufficient based on the definitions used in this paper. In areas where there are resource concerns, managers should implement practices that help ensure uniformity and sustainability of grazing while improving or maintaining favorable animal performance without excessive costs. Only a limited amount of information is currently available on the effectiveness of various distribution management practices on a site-specific basis, and even less is known about the economic impacts of these practices. Continued research on livestock grazing distribution is warranted, especially development of innovative management techniques, evaluation of habitat and management impacts on animal performance, and economic analyses.

\section{LITERATURE CITED}

Allen, A. W., J. G. Cook, and M. J. Armbruster. 1984. Habitat suitability index models: Pronghorn. Washington, DC: US Fish and Wildlife Service. FWS/OBS82/10.65. 22 p.

BAILEY, D. W. 1995. Daily selection of feeding areas by cattle in homogeneous and heterogeneous environments. Applied Animal Behavior Science 45:183-200.
Balley, D. W., J. E. Gross, E. A. Laca, L. R. Rittenhouse, M. B. Coughenour, D. M. SWIFT, AND P. L. SIMS. 1996. Mechanisms that result in large herbivore grazing distribution patterns. Journal of Range Management 49:386-400.

Bailey, D. W., D. D. Kress, D. C. Anderson, D. L. Boss, and K. C. Davis. 2001 a. Evaluation of F1 crosses from Angus, Charolais, Salers, Piedmontese, Tarentaise and Hereford sires V: grazing distribution patterns. Proceedings, Western Section, American Society of Animal Science 52:110-113.

Bailey, D. W., D. D. Kress, D. C. Anderson, D. L. Boss, and E. T. Miller. 2001b. Relationship between terrain use and performance of beef cows grazing foothill rangeland. Journal of Animal Science 79:1883-1891.

Bailey, D. W., E. T. Miller, and G. R. Welling. 2000. Wind affects low-moisture molasses supplement consumption in cold weather. Abstracts, Society for Range Management Annual Meeting; 12-18 February 2000; Boise, ID. Denver, CO: Society for Range Management. $49 \mathrm{p}$.

Bailey, D. W., And L. R. RitTenhouse. 1989. Management of cattle distribution. Rangelands 11:159-161.

Balley, D. W., AND G. R. Weluing. 1999. Modification of cattle grazing distribution with dehydrated molasses supplement. Journal of Range Management 52:575-582.

Balley, D. W., G. R. Welling, and E. T. Miller. 2001c. Cattle use of foothills rangeland near dehydrated molasses supplement. Journal of Range Management 54:338-347.

Ball, J. P., K. Danell, and P. Sunesson. 2000. Response of a herbivore community to increased food quality and quantity: an experiment with nitrogen fertilizer in a boreal forest. Journal of Applied Ecology 37:247-255.

Beaver, J. M., AND B. E. OLson. 1997. Winter range use by cattle of different ages in southwestern Montana. Applied Animal Behavior Science 51:1-13.

Biondini, M. E., A. A. Steuter, and R. G. Hamilton. 1999. Bison use of fire-managed remnant prairies. Journal of Range Management 52:454-461.

BRoCk, B. L., AND C. E. OWENSBY. 2000. Predictive models for grazing distribution: a GIS approach. Journal of Range Management 53:39-46.

ButLeR, P. J. 2000. Cattle distribution under intensive herded management. Rangelands 22:21-23.

Cook, C. W. 1966. Factors affecting utilization of mountain slopes. Journal of Range Management 19:200-204.

CoppeDge, B. R., AND J. H. SHAW. 1998. Bison grazing patterns on seasonally burned tallgrass prairie. Journal of Range Management 51:258-264.

Coughenour, M. B. 1991. Spatial components of plant-herbivore interactions in pastoral, ranching and native ungulate ecosystems. Journal of Range Management 44:530-542.

Davison, J., AND J. Neufeld. 1999. Reducing the impacts associated with cattle grazing on a riparian area by employing alternative grazing management strategies. Reno, NV: University of Nevada, Reno. Final Report OSPA 1950226. $19 \mathrm{p}$.

DelCurto, T., M. Porath, M. Mclnnis, P. Momont, and C. Parsons. 1999. Management strategies for optimal beef cattle distribution and use of mountain riparian meadows. In: K. L. Launchbaugh, K. D. Sanders, and J. C. Mosley [eds.]. Grazing behavior of livestock and wildlife. Moscow, ID: Idaho Forest, Wildlife and Range Experimental Station. Bulletin 70. p 119-129.

Futs, E. R. 1992a. Ecosystem modification created by patch-overgrazing semi-arid grassland. Journal of Arid Environments 23:59-69.

Futs, E. R. 1992b. Semi-arid and arid rangelands: a resource under siege due to patch-selective grazing. Journal of Arid Environments 22:191-193.

GanSKOPP, D. 2001. Manipulating cattle distribution with salt and water in large arid-land pastures: a GPS/GIS assessment. Applied Animal Behavior Science 73:251-262.

Ganskopp, D., R. CRuz, and D. E. Johnson. 2000. Least-effort pathways? A GIS analysis of livestock trails in rugged terrain. Applied Animal Behavior Science 68:179-190.

Gillen, R. L., W. C. Krueger, and R. F. Miller. 1984. Cattle distribution on mountain rangeland in northeastern Oregon. Journal of Range Management 37: 549-553.

Harris, N. R., D. E. Johnson, M. R. George, and N. K. McDougald. 2002. The effect of topography, vegetation, and weather on cattle distribution at the San Joaquin Experimental Range, California. USDA Forest Service General 
Technical Report PSW-GTR-184. p 53-63. Available from: USDA Forest Service, Albany, CA.

Hart, R. H., K. W. Hepworth, M. A. Smith, and J. W. Waggoner, JR. 1991. Cattle grazing behavior on a foothill elk winter range in southeastern Wyoming. Journal of Range Management 44:262-266.

Hart, R. H., M. J. Samuel, P. S. Test, And M. A. Smith. 1988. Cattle, vegetation, and economic responses to grazing systems and grazing pressure. Journal of Range Management 41:282-286.

HoLECHEK, J. L. 1988. An approach for setting the stocking rate. Rangelands 10:10-14.

Holechek, J. L., R. D. Pieper, and C. H. Herbel. 2001. Range management principles and practices. 4th ed. Upper Saddle River, NJ: Prentice Hall. 587 p.

Hooper, J. F., J. P. Workman, J. B. Grumbles, and C. W. Cook. 1969. Improved livestock distribution with fertilizer-a preliminary economic evaluation. Journal of Range Management 22:108-110.

Houseal, G. A., And B. E. OLSon. 1995. Cattle use of microclimates on a northern latitude winter range. Canadian Journal of Animal Science 75:501-507.

Howery, L. D., F. D. Provenza, and R. E. Banner. 1998. Social and environmental factors influence cattle distribution. Applied Animal Behavior Science 55:231-244.

Howery, L. D., F. D. Provenza, R. E. Banner, and C. B. Scott. 1996. Differences in home range and habitat use among individuals in a cattle herd. Applied Animal Behavior Science 49:305-320.

May, G. J., R. D. Jones, M. R. Langemeier, and K. C. Dhuyvetter. 2002. Influence of grazing lease terms on economic optimal stocking rates. Journal of Range Management 55:461-468.

McDougald, N. K., W. E. Frost, and D. E. Jones. 1989. Use of supplemental feeding locations to manage cattle use on riparian areas of hardwood rangelands. Proceedings of the California Riparian Systems Conference, Davis, CA. Washington, DC: USDA Forest Service. USDA Forest Service General Technical Report PSW-110. p 124-126.

Mclıvaln, E. H., AND M. C. Shoop. 1971. Shade for improving cattle gains and rangeland use. Journal of Range Management 24:181-184.

Miner, J. R., J. C. Buckhouse, AND J. A. Moore. 1992. Will a water trough reduce the amount of time hay-fed livestock spend in the stream (and therefore improve water quality)? Rangelands 14:35-38.

Moen, R., J. Pastor, and Y. Cohen. 1997. Accuracy of GPS telemetry collar locations with differential correction. Journal of Wildlife Management 61:530-539.

Muggler, W. F. 1965. Cattle distribution on steep slopes. Journal of Range Management 18:255-257.

National Research Council. 1996. Nutrient requirements of beef cattle. 7th ed. Washington, DC: National Academy Press. 242 p.

OLSON, B. E., AND R. T. Wallander. 2002. Influence of winter weather and shelter on activity. Canadian Journal of Animal Science 82:491-501.

Olson, B. E., R. T. Wallander, and J. A. Paterson. 2000. Do windbreaks minimize stress on cattle grazing foothill winter range? Canadian Journal of Animal Science 80:265-272.

Parsons, C. T., P. A. Momont, T. DelCurto, M. Mclnnis, and M. L. Porath. 2003. Cattle distribution patterns and vegetation use in mountain riparian areas. Journal of Range Management 56:334-341.

Pinchak, W. E., M. A. Smith, R. H. Hart, and J. W. Waggoner, Jr. 1991. Beef cattle distribution patterns on foothill range. Journal of Range Management 44: 267-275.

Porath, M. L., P. A. Momont, T. DelCurto, N. R. Rimbey, J. A. Tanaka, and M. Mclnnis. 2002. Offstream water and trace mineral salt as management strategies for improved cattle distribution. Journal of Animal Science 80: 346-356.

Provenza, F. D., J. A. Pfister, and C. D. Cheney. 1992. Mechanisms of learning in diet selection with reference to phytotoxicosis in herbivores. Journal of Range Management 45:36-45.

Provenza, F. D., J. J. Villalba, L. E. Dziba, S. B. Atwood, and R. E. Banner. 2003.
Linking herbivore experience, varied diets, and plant biochemical diversity. Small Ruminant Research 49:257-274.

Rhodes, B. J., AND C. B. Marlow. 1997. Intensive range riding for improving livestock distribution. Abstracts, Society for Range Management Annual Meeting; 16-21 February 1997; Rapid City, SD. Denver, C0: Society for Range Management, 38-39.

Rittenhouse, L. R., and D. W. Bailey. 1996. Spatial and temporal distribution of nutrients. In: M. B. Judkins and F. T. McCollum, III [eds.]. Proceedings of the 3rd Grazing Livestock Nutrition Conference. Proceedings, Western Section, American Society of Animal Science 47(Suppl 1):51-61.

Roath, L. R., and W. C. Krueger. 1982. Cattle grazing and behavior on a forested range. Journal of Range Management 35:332-338.

RUYLE, G. B., AND R. W. RicE. 1996. Aspects of forage availability and short-term intake influencing range livestock production. In: M. B. Judkins and F. T. McCollum, III [eds.]. Proceedings of the 3rd Grazing Livestock Nutrition Conference. Proceedings, Western Section, American Society of Animal Science 47(Suppl 1):40-50.

Senft, R. L. 1989. Hierarchical foraging models: effects of stocking and landscape composition on simulated resource use by cattle. Ecological Modeling 46: 283-303.

Senft, R. L., M. B. Coughenour, D. W. Bailey, L. R. Rittenhouse, O. E. Sala, and D. M. SwIF. 1987. Large herbivore foraging and ecological hierarchies. BioScience 37:789-799.

Senft, R. L., L. R. Rittenhouse, and R. G. Woodmansee. 1985a. Factors influencing patterns of cattle grazing behavior on shortgrass steppe. Journal of Range Management 38:82-87.

Senft, R. L., L. R. Rittenhouse, and R. G. Woodmansee. 1985b. Factors influencing selection of resting sites by cattle on shortgrass steppe. Journal of Range Management 38:295-299.

SkovLIN, J. M. 1957. Range riding-the key to range management. Journal of Range Management 10:269-271.

Smith, M. A., J. D. Rodgers, J. L. Dodd, And Q. D. Skinner. 1992. Declining forage availability effects on utilization and community selection by cattle. Journal of Range Management 45:391-395.

Stephens, D. W., and J. R. KreBs. 1986. Foraging theory. Princeton, NJ: Princeton University Press. $247 \mathrm{p}$.

Stillings, A. M., J. A. Tanaka, N. R. Rimbey, T. DelCurto, P. A. Momont, and M. L. Porath. 2003. Economic implications of off-stream water developments to improve riparian grazing. Journal of Range Management 56: 418-424.

ThomAs, J. W. 1979. Introduction. In: J. W. Thomas [ed.]. Wildlife habitats in managed forests-The Blue Mountains of Oregon and Washington. USDA Forest Service Handbook 553. Washington, DC: USDA Forest Service. p 1021.

Trefethen, J. B. 1964. Wildlife management and conservation. Boston: DC Heath and $\mathrm{Co} .120 \mathrm{p}$.

US FISH AND WILdLIFE Service. 1976. Habitat evaluation procedures. Washington, DC: Division of Ecological Services. $30 \mathrm{p}$.

Valentine, K. A. 1947. Distance from water as a factor in grazing capacity of rangeland. Journal of Forestry 45:749-754.

Vallentine, J. F. 2001. Grazing management. 2nd ed. San Diego, CA: Academic Press. $65 \mathrm{p}$

WiLliams, R. E. 1954. Modern methods of getting uniform use of ranges. Journal of Range Management 7:77-81.

Williams, K., AND J. LACEY. 1995. A guide for evaluating additional fencing and water development. Rangelands 17:7-12.

Workman, J. P., AND J. F. Hooper. 1968. Preliminary economic evaluation of cattle distribution practices on mountain rangelands. Journal of Range Management 21:301-304. 